\title{
Human parasitism by the exotic tick Dermacentor variabilis (Parasitiformes: Ixodida) in Brazil: report of an imported case
}

\author{
Parasitismo humano pelo carrapato exótico Dermacentor variabilis \\ (Parasitiformes: Ixodida) no Brasil: relato de um caso importado \\ Thiago Fernandes Martins ${ }^{1,2 \star}$ (1); Adriano Pinter $^{1}$
}

'Departamento de Laboratórios Especializados, Superintendência de Controle de Endemias, Secretaria de Estado da Saúde de São Paulo, São Paulo, SP, Brasil

${ }^{2}$ Departamento de Medicina Veterinária Preventiva e Saúde Animal, Faculdade de Medicina Veterinária e Zootecnia, Universidade de São Paulo, São Paulo, SP, Brasil

How to cite: Martins TF, Pinter A. Human parasitism by the exotic tick Dermacentor variabilis (Parasitiformes: Ixodida) in Brazil: report of an imported case. Braz J Vet Parasitol 2022; 31(1): e017121. https://doi.org/10.1590/S1984-29612021093

\begin{abstract}
In June 2012, a tick was found parasitizing a man in the city of São Paulo, who had recently returned from a visit to Pennsylvania, in the northeast of the United States. The tick was removed and sent to the São Paulo State Department of Health, where it was identified as a male of the species Dermacentor variabilis (Say, 1821), according to the literature and taxonomic keys. The tick was subjected to a PCR test to search for rickettsiae, but the result was negative. The fact that a human entered Brazilian territory unaware that he was parasitized by a hard tick not belonging to the national tick fauna is significant because of the possibility that an exotic species could be introduced and take hold in this country. Another major risk to public health is that this arthropod could be infected with the bacterium Rickettsia rickettsii, as this ectoparasite is the main vector of Spotted Fever on the East Coast of North America.
\end{abstract}

Keywords: Acari, Ixodidae, public health, Brazilian traveler, United States of America.

\begin{abstract}
Resumo
Em junho de 2012, foi enviado ao serviço da Secretaria de Estado da Saúde de São Paulo um carrapato que foi encontrado em parasitismo sobre um homem adulto na cidade de São Paulo, que havia chegado recentemente de uma viagem de turismo aos Estados Unidos, onde visitou o estado da Pensilvânia, situado na região Nordeste Americana. O carrapato foi identificado como um macho da espécie Dermacentor variabilis, (Say, 1821), de acordo com a literatura e chaves taxonômicas, sendo submetido ao teste da PCR para pesquisa de riquétsias, porém o resultado foi negativo. O fato de um ser humano ter cruzado a fronteira do Brasil, parasitado, sem o seu prévio conhecimento, por um carrapato duro, não pertencente à ixodofauna nacional, é de grande importância pela chance de introdução e estabelecimento no território brasileiro de uma espécie exótica. Outro grande risco para a saúde pública é que esse artrópode poderia estar infectado com a bactéria Rickettsia rickettsii, pois esse ectoparasito é o principal vetor da Febre Maculosa na costa Leste Norte Americana.
\end{abstract}

Palavras-chave: Acari, Ixodidae, saúde pública, viajante brasileiro, Estados Unidos da América. 
The hard tick Dermacentor variabilis (Say, 1821) occurs throughout Canada, the United States of America and Mexico, parasitizing a large diversity of wild and domestic mammals during its adult stage, and mainly rodents during its immature stages (Guglielmone et al., 2014; Guglielmone \& Robbins, 2018). In addition to being of veterinary importance, it is of medical importance because it accidentally parasitizes humans and is a well-known vector of the bacterium Rickettsia rickettsii, the etiological agent of Rocky Mountain Spotted Fever (Furman \& Loomis, 1984; Guglielmone \& Robbins, 2018). Few studies to evaluate the vector competence of $D$. variabilis to transmite of Borrelia burgdorferi sensu lato have been carried out so far, whereby it has not been experimentally confirmed this tick species as a spirochete vectors (Eisen, 2020).

In Brazil, reports of local native ticks parasitizing human beings are common, particularly the species belonging to the genus Amblyomma (Guglielmone \& Robbins, 2018). On the other hand, reports of imported exotic ticks parasitizing humans in Brazilian territory are rare and are usually associated with travelers (Serra-Freire et al., 2015; Faccini-Martínez et al., 2021).

The objectives of this study were two-fold. One, to offer the first report in Brazilian territory, to the best of our knowledge, of parasitism by the tick $D$. variabilis on a Brazilian tourist returning to his home country after a visit to the United States of America (USA). And secondly, to determine the presence or absence of rickettsiae in this tick specimen.

On July 5, 2012, the office of Brazil's National Health Surveillance Agency (ANVISA) at São Paulo International Airport forwarded a tick to the Superintendence of Endemic Disease Control (SUCEN) of the São Paulo State Department of Health (SES/SP).

The tick was found parasitizing an adult man who was a resident of the city of São Paulo, Brazil, upon his arrival at the aforementioned airport after a 9-hour overnight flight from the USA, where he was traveling in the state of Pennsylvania, located in the northeastern region of the country. The man noticed the tick attached to his skin after disembarking from the aircraft, whereupon he went to the office of ANVISA airport to report the finding. The tick, the only one found on the newly arrived passenger, was removed and stored in pure ethanol. No further information about was obtained about which cities he had visited or if he had been traveling in rural or forest areas.

The tick was examined under a LEICA M205 C stereomicroscope at the Laboratory of Medical Entomology of SUCEN, and was identified based on specific taxonomic keys and the species' morphological characteristics published in the literature (Cooley, 1938; Arthur, 1960; Furman \& Loomis, 1984). In addition, the specimen sent by ANVISA to SUCEN was analyzed by PCR, targeting the gltA gene, primers CS-5 and CS-6, to determine the presence or absence of Rickettsia of the Spotted Fever group, as described by Labruna et al. (2004).

An acarological analysis indicated the specimen was a male of the species D. variabilis and the PCR test showed it was negative for Spotted Fever Group Rickettsia. The taxonomic and rickettsial findings were sent to the man who reported the discovery of the tick, and although the especimen was negative for rickettsial infection, he was asked to check for spotted fever symptoms for the next 15 days. In addition, all the passenger that had sat next to him or in the rows in front and behind him on the flight were contacted and asked to check for signs of spotted fever. However, these passengers reported no symptoms.

According to Estrada-Peña \& Jongejan (1999), this tick is often found parasitizing humans. However, Guglielmone \& Robbins (2018) state that the immature stages of this tick species are rarely found on humans, although adults ticks are commonly reported. Therefore, the human parasitism by an adult tick found in this study is in agreement with data in the literature. The occurrence of human parasitism is also corroborated by other works in the literature that reported travelers parasitized by D. variabilis in Australia, Panama and New Zealand (Halliday \& Sutherst, 1990; Bermúdez et al., 2010, 2019; Heath \& Hardwick, 2011).

To date, 14 exotic tick species have been reported in Brazil but have probably not become established, including species of several genera: Amblyomma argentinae Neumann, 1905, Amblyomma crassum Robinson, 1926, Amblyomma darwinii Hirst \& Hirst, 1910, Amblyomma parvitarsum Neumann, 1901, Bothriocroton undatum Fabricius, 1775 (published as Aponomma decorosum), Dermacentor andersoni Stiles, 1908, Hyalomma aegyptium Linnaeus, 1758, Hyalomma dromedarii Koch, 1844, Hyalomma marginatum Koch, 1844, Rhipicephalus bursa Canestrini \& Fanzago, 1878, Rhipicephalus evertsi Neumann, 1897, Ixodes percavatus Neumann, 1906, (sensu lato), Ixodes woodi Bishopp, 1911 and Otobius megnini (Dugès, 1883) (Dantas-Torres et al., 2009; Amorim et al., 2013; Serra-Freire et al., 2015; Faccini-Martínez et al., 2021; Labruna et al., 2020).

On the other hand, only three exotic tick species have become established in Brazil and are currently considered pests and vectors of pathogens for domestic animals: Dermacentor nitens Neumann, 1897, Rhipicephalus microplus 
Canestrini, 1888, and Rhipicephalus sanguineus Latreille, 1806 (sensu lato) (Aragão, 1936; Barros-Battesti et al., 2006). It is worth noting that these three exotic species that have become established in Brazil have already been found on humans in different regions of the national territory (Guglielmone \& Robbins, 2018).

Although the tick $D$. nitens is a vector of Babesia caballi in horses and has been sporadically recorded on humans in Brazil by Guglielmone et al. (2006) and Serra-Freire (2010, 2014), according to Guglielmone \& Robbins (2018), human parasitism by this tick species in Brazil requires confirmation, a fact recently confirmed by Szabó et al. (2020). On the other hand, the species R. microplus, which has already been found on humans working in direct contact with livestock, is important for animal health because it transmits Anaplasma marginale, Babesia bovis and Babesia bigemina (Labruna et al., 2005; Barros-Battesti et al., 2006). Lastly, the tick R. sanguineus s. I. not only transmits Anaplasma platys, Babesia canis vogeli, Babesia gibsoni, Ehrlichia canis and Hepatozoon canis to dogs, but has also been found to be infected with the bacterium $R$. rickettsii, thus representing a public health threat in this country (Barros-Battesti et al., 2006; Ogrzewalska et al., 2012).

Based on the above-mentioned facts, the identification of $D$. variabilis on a Brazilian traveler is an indication not only of the imminent risk of the introduction and establishment of exotic ticks in Brazil but also of the possibility of importation of pathogens from other countries, since this tick species is native to North America and is an important vector for $R$. rickettsii on that continent.

\section{Acknowledgements}

The authors of this study gratefully acknowledge the financial support of FAPESP (São Paulo Research Foundation) (FAPESP Process No. 2019/03167-0, 2020/05987-1).

\section{References}

Amorim M, Serra-Freire NM, Pedro MJV, Teixeira RHF, Gazêta GS. Caso índice de Amblyomma crassum Robinson, 1926 (Acari: Ixodidae) em sucuri (Reptilia: Ophidia) no Brasil. Rev Uniabeu 2013; 6(14): 355-362.

Aragão HB. Ixodidas brasileiros e de alguns paizes limitrophes. Mem Inst Oswaldo Cruz 1936; 31(4): 759-843. http://dx.doi. org/10.1590/S0074-02761936000400004.

Arthur DR. Ticks, a monograph of the Ixodoidea. Part V: on the genera Dermacentor, Anocentor, Cosmiomma, Boophilus \& Margaropus. London: Cambridge University Press; 1960.

Barros-Battesti DM, Arzua M, Bechara GH. Carrapatos de importância médico-veterinária da Região Neotropical: um guia ilustrado para identificação de espécies. São Paulo; Butantan; 2006.

Bermúdez S, Suárez JA, Domínguez L, Gundacker ND. Infectious disease physicians as host: Dermacentor variabilis (Ixoidad: Ixodidae) in a Panamanian returning from Wisconsin, United States. Syst Appl Acarol 2019; 24(10): 1814-1816. http://dx.doi. org/10.11158/saa.24.10.2.

Bermúdez SE, Miranda RJ, Zaldívar Y, Page K. Dermacentor variabilis (Ixodida: Ixodidae) in Panama: report associated with tourism. J Vector Ecol 2010; 35(1): 208-209. http://dx.doi.org/10.1111/j.1948-7134.2010.00079.x. PMid:20618669.

Cooley RA. The genera Dermacentor and Otocentor (Ixodidae) in the United States, with studies in variation. Washington D.C.: National Institute of Health Bulletin; 1938.

Dantas-Torres F, Onofrio VC, Barros-Battesti DM. The ticks (Acari: Ixodida: Argasidae, Ixodidae) of Brazil. Syst Appl Acarol 2009; 14(1): 30-49. http://dx.doi.org/10.11158/saa.14.1.4.

Eisen L. Vector competence studies with hard ticks and Borrelia burgdorferi sensu lato spirochetes: a review. Ticks Tick Borne Dis 2020; 11(3): 101359. http://dx.doi.org/10.1016/j.ttbdis.2019.101359. PMid:32067949.

Estrada-Peña A, Jongejan F. Ticks feeding on humans: a review of records on human-biting Ixodoidea with special reference to pathogen transmission. Exp Appl Acarol 1999; 23(9): 685-715. http://dx.doi.org/10.1023/A:1006241108739. PMid:10581710.

Faccini-Martínez ÁA, Martins TF, Silveira I, Labruna MB. Detection of Dermacentor andersoni (Acari: Ixodidae) in Brazil on a human traveler returning from the United States. J Med Entomol 2021; 58(2): 947-949. http://dx.doi.org/10.1093/jme/tjaa204. PMid:32990727.

Furman DP, Loomis EC. The ticks of California (Acari: Ixodida). Berkeley: University of California Press; 1984.

Guglielmone AA, Beati L, Barros-Battesti DM, Labruna MB, Nava S, Venzal JM, et al. Ticks (Ixodidae) on humans in South America. Exp Appl Acarol 2006; 40(2): 83-100. http://dx.doi.org/10.1007/s10493-006-9027-0. PMid:17103085. 
Guglielmone AA, Robbins RG, Apanaskevich DA, Petney TN, Estrada-Peña A, Horak IG. The hard ticks of the world: (Acari: Ixodida: Ixodidae). London; Springer; 2014. http://dx.doi.org/10.1007/978-94-007-7497-1.

Guglielmone AA, Robbins RG. Hard ticks (Acari: Ixodida: Ixodidae) parasitizing humans: a global overview. London; Springer; 2018. http://dx.doi.org/10.1007/978-3-319-95552-0.

Halliday RB, Sutherst RW. An Australian record of the American dog tick Dermacentor variabilis, and the risk of its establishment outside North America. Exp Appl Acarol 1990; 8(1-2): 65-70. http://dx.doi.org/10.1007/BF01193382. PMid:2307072.

Heath ACG, Hardwick S. The role of humans in the importation of ticks to New Zealand: a threat to public health and biosecurity. N Z Med J 2011; 124(1339): 67-82. PMid:21952332.

Labruna MB, Camargo LMA, Terrassini FA, Ferreira F, Schumaker TTS, Camargo EP. Ticks (Acari: Ixodidae) from the State of Rondonia, western Amazon, Brazil. Syst Appl Acarol 2005; 10(0): 17-32. http://dx.doi.org/10.11158/saa.10.1.4.

Labruna MB, Muñoz-leal S, Vanstreels RET, Acosta ICL, Repenning M, Martins TF, et al. Records of Ixodes percavatus sensu lato on Atlantic yellow-nosed albatrosses (Thalassarche chlororhynchos) on the Brazilian coast and offshore waters. Syst Appl Acarol 2020; 25(6): 957-962. http://dx.doi.org/10.11158/saa.25.6.1.

Labruna MB, Whitworth T, Bouyer DH, McBride JL, Camargo MA, Camargo EP, et al. Rickettsia bellii and Rickettsia amblyommii in Amblyomma ticks from the state of Rondônia, Western Amazon, Brazil. J Med Entomol 2004; 41(6): 1073-1081. http://dx.doi. org/10.1603/0022-2585-41.6.1073. PMid:15605647.

Ogrzewalska M, Saraiva DG, Moraes-Filho J, Martins TF, Costa FB, Pinter A, et al. Epidemiology of Brazilian spotted fever in the Atlantic Forest, state of São Paulo, Brazil. Parasitology 2012; 139(10): 1283-1300. http://dx.doi.org/10.1017/S0031182012000546. PMid:22716923.

Serra-Freire NM, Amorim M, Gazêta GS. Diagnostic of Ixodes woodi Bishopp, 1911 (Acari: Ixodidae) in Brazil: immigration on Homo sapiens - case report. Rev Bras Med Vet 2015; 37(1): 97-99.

Serra-Freire NM. Joined species of hard ticks on Amerindians, Quilombolas and domestic animals in the State of Paraiba. Rev Uniabeu 2014; 7(17): 61-68.

Serra-Freire NM. Occurrence of ticks (Acari: Ixodidae) on human hosts, in three municipalities in the State of Pará, Brazil. Rev Bras Parasitol Vet 2010; 19(3): 141-147. http://dx.doi.org/10.1590/S1984-29612010000300003. PMid:20943016.

Szabó MPJ, Martins TF, Barbieri ARM, Costa FB, Soares HS, Tolesano-Pascoli GV, et al. Ticks biting humans in the Brazilian savannah: attachment sites and exposure risk in relation to species, life stage and season. Ticks Tick Borne Dis 2020; 11(2): 101328. http:// dx.doi.org/10.1016/j.ttbdis.2019.101328. PMid:31767495. 